\title{
Maxillary full-arch fixed dental prosthesis of the elderly patient with worn dentition
}

\author{
Jae hyun Lee, Yeon jo Choi, Jae jun Ryu* \\ Division of Prosthodontics, Department of Dentistry, Anam Hospital, Korea University Medical Center, Seoul, Republic of Korea
}

Tooth wear, one of the physiological changes in the elderly patient's mouth, generally does not require treatment, but requires prosthodontic restoration when occlusal disharmony, poor masticatory function, pulp exposure occurs. One of the primary considerations in prosthodontic restoration for tooth wear is vertical dimension. It is necessary to make an accurate diagnosis and analysis, correct judgement of the interdental relationship for predictive treatment plan. A step-by-step approach considering dental care for aged is also required. In this case, a 93-year-old male patient presented with worn dentition and mobility of existing fixed dental prosthesis. After diagnosis and evaluation, maxillary rehabilitation without any change in the occlusal vertical dimension was performed and this shows satisfactory results both functionally and morphologically. (J Dent Rehabil Appl Sci 2017;33(2):154-62)

Key words: dental care for aged; tooth wear; vertical dimension

\begin{abstract}
서론
고령화 사회가 진행됨에 따라 노인 환자 구강의 생리 적 변화에 대한 관심도 점차 높아지고 있다. 과거부터 치 아 마모와 연령 간의 상관관계에 대한 보고는 활발히 이 루어져왔다. ${ }^{1}$ 마모된 치열을 지닌 환자의 보철 수복 시 우 선적으로 고려되는 사항들 중 하나가 바로 수직교합고경 에 대한 고려이다. Dawson, ${ }^{2}$ Ramfjord와 Blankenship ${ }^{3}$ 은 마모와 수직교합고경의 관계에 있어서 마모에 따른 수직교합고경의 감소가 반드시 동반되는 것은 아니며, Turner와 Missirlian ${ }^{4}$ 은 마모에 따른 보철적 수복 치료 시 수직교합고경에 대한 정확한 판단 및 분류를 강조하 였다. 이에 마모된 치열을 지닌 노인 환자의 보철 수복 시 정확한 진단 및 분석과 예지성 있는 치료계획을 통해 악 간관계에 대한 올바른 판단이 요구되며, 고령의 환자 나 이를 감안한 단계별 치료접근을 필요로 한다. ${ }^{5}$
\end{abstract}

*Correspondence to: Jae jun Ryu

Professor, Department of Prosthodontics, Anam Hospital, Korea University,

73, Inchon-ro, Seongbuk-gu, Seoul, 02841, Republic of Korea

Tel: +82-2-920-5423, Fax: +82-2-921-7348, E-mail: koprosth@unitel.co.kr

Received: February 17, 2017/Last Revision: March 21, 2017/Accepted: April 10,
본 증례는 93세 남자 환자로 전반적인 치아 마모 및 기존 고정성 보철물의 동요도를 보이고 있었다. 진단 및 평가 결과 수직교합고경을 유지한 상악 전악 보철 수 복이 필요한 상태로 판단되었고, 수직교합고경을 유지 한 채 임시 보철물로 수복 후 3 개월 간 경과 관찰을 시 행하였다. 금속 도재관을 이용한 long span fixed dental prosthesis로 상악 전악 구강회복술을 시행하였으며, 기 능 및 형태적으로 만족할만한 결과를 보여 보고하는 바 이다.

\section{증례보고}

상기 환자는 93세 남성으로 상악 전치부 고정성 보철 물의 동요도 및 하악 좌측 구치부의 치아치조농양과 함 께 전반적인 치아 마모를 주소로 내원하였다. 임상 및 방 사선학적 검사를 시행하였으며, 그 결과 \#21에서 \#24로

Copyright(C 2017 The Korean Academy of Stomatognathic Function and Occlusion. (c) It is identical to Creative Commons Non-Commercial License. 

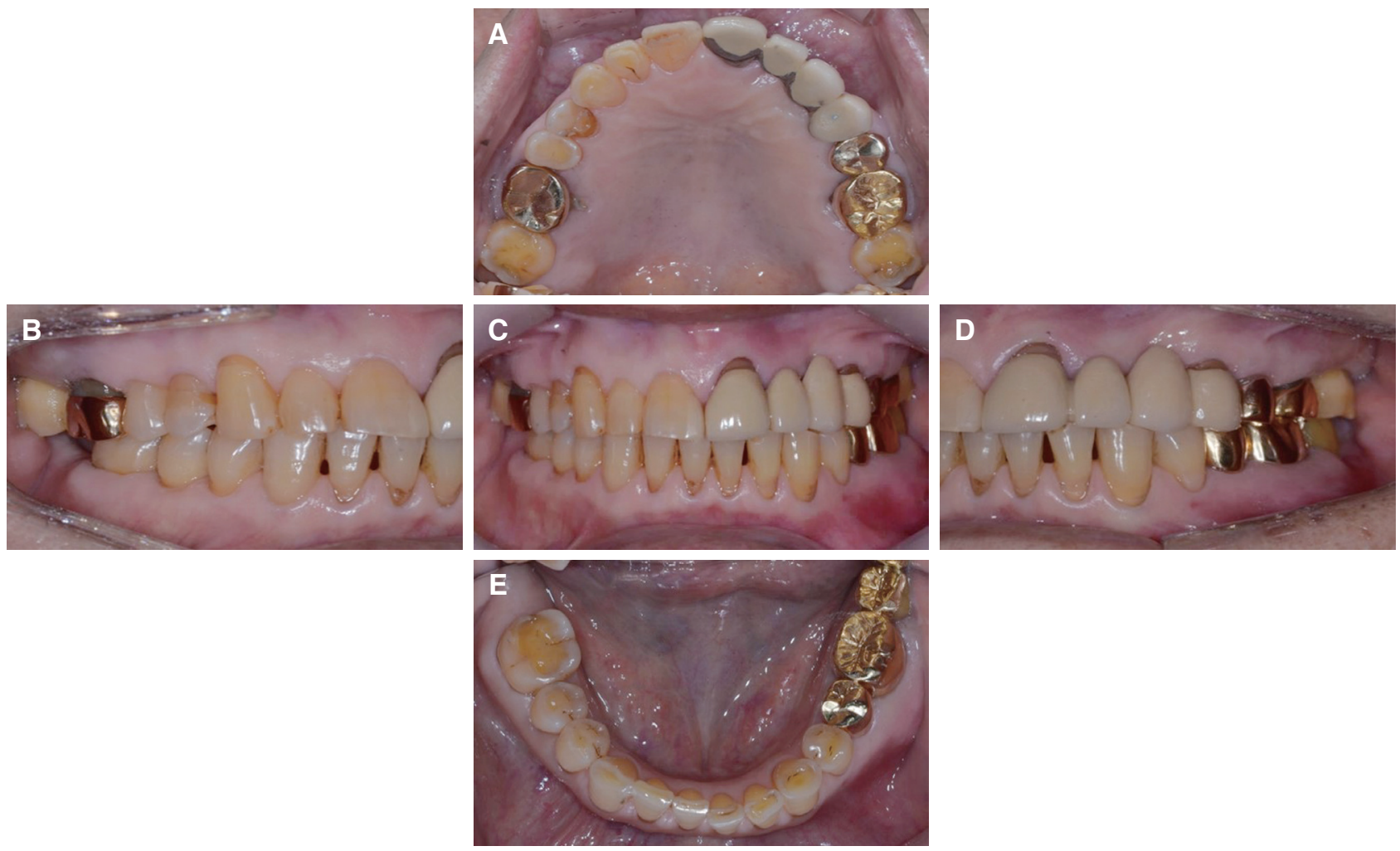

Fig. 1. Intra-oral status in the initial examination. Generalized toothwear was shown. Dentoalveolar abscess was observed around \#36. \#47 was missing. (A) Maxillary occlusal view, (B) Right lateral view, (C) Frontal view at maximum inter-cuspal position, (D) Left lateral view, (E) Mandibular occlusal view.

이어지는 고정성 보철물에서 \#21을 중심으로 3도 동요 도를 보였고, \#16에서 치아 주위 치조골 소실에 따른 3 도 동요도를 보였다. 또한 \#25에서 2도 동요도 및 \#26 에서 1도 동요도를 보였으며, \#17 원심면에서 치아 우식 이 관찰되었고, \#36을 원인치로 한 치아치조농양이 관찰 되었다(Fig. 1, 2). 임상 및 방사선학적 검사에서 측두하악 관절장애는 관찰되지 않았다(Fig. 3).

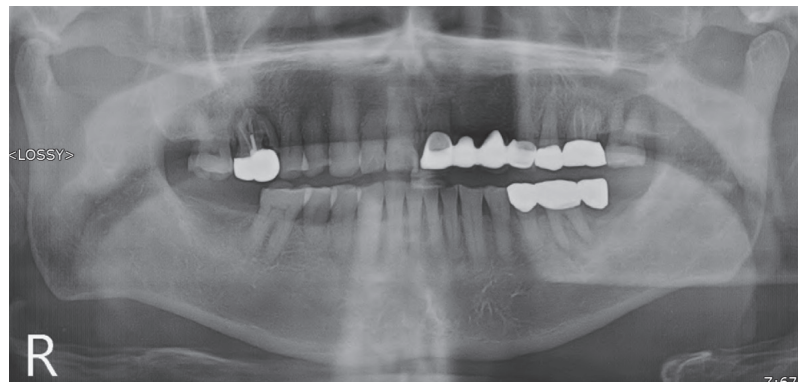

Fig. 2. Initial panoramic radiographic image. Alveolar bone resorption was observed around \#16, \#21, \#25. Distal caries was observed at \#17. Periapical radiolucency was observed at \#36.
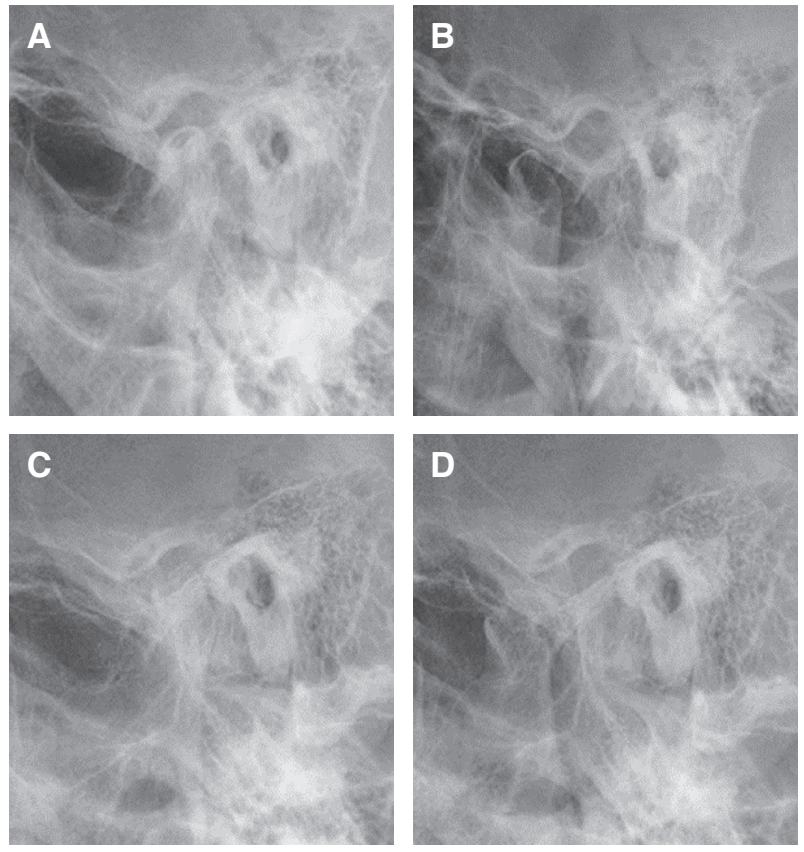

Fig. 3. Initial TMJ series. No evidence of pathologic change. (A) Right side in closed state, (B) Right side in opened state, (C) Left side in closed state, (D) Left side in opened state. 

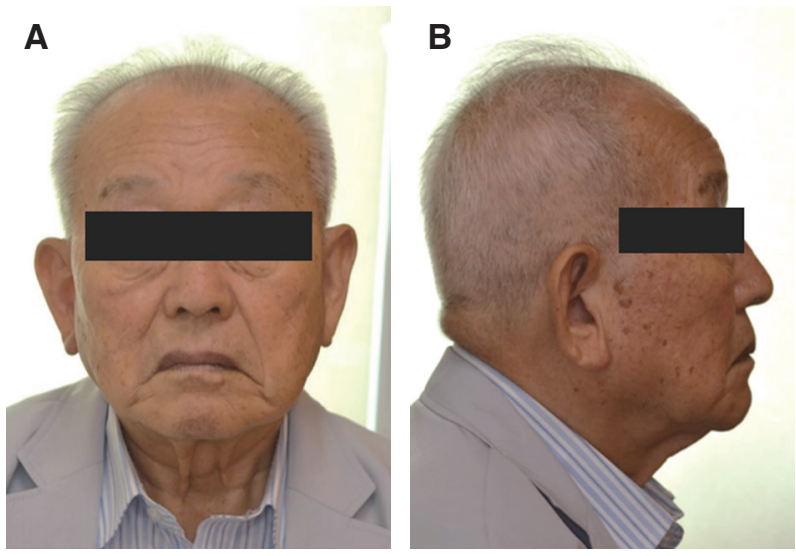

Fig. 4. Vertical dimension analysis. In the Willis analysis, the ratio of the distance from the pupil of the eyes to the parting line of the lips and the distance from the bony shelf under the nose to the bottom of the mandible was 1:0.97. No decrease in the occlusal vertical dimension was observed. (A) Frontal view, (B) Lateral view.

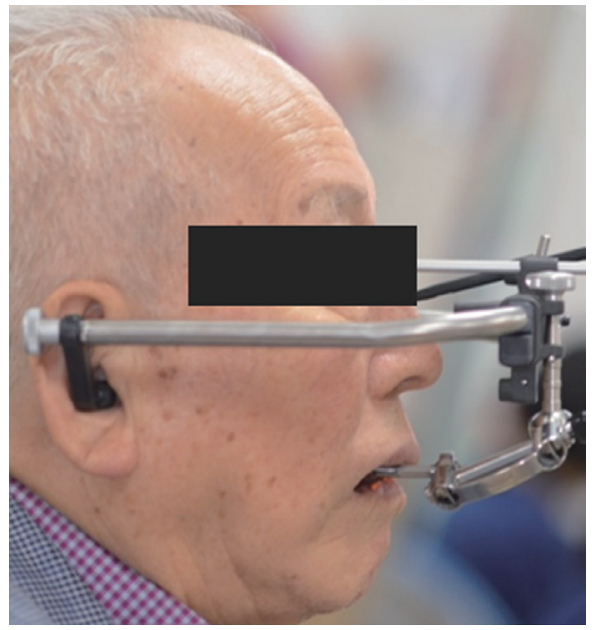

Fig. 5. Face-bow transfer (Right side view).
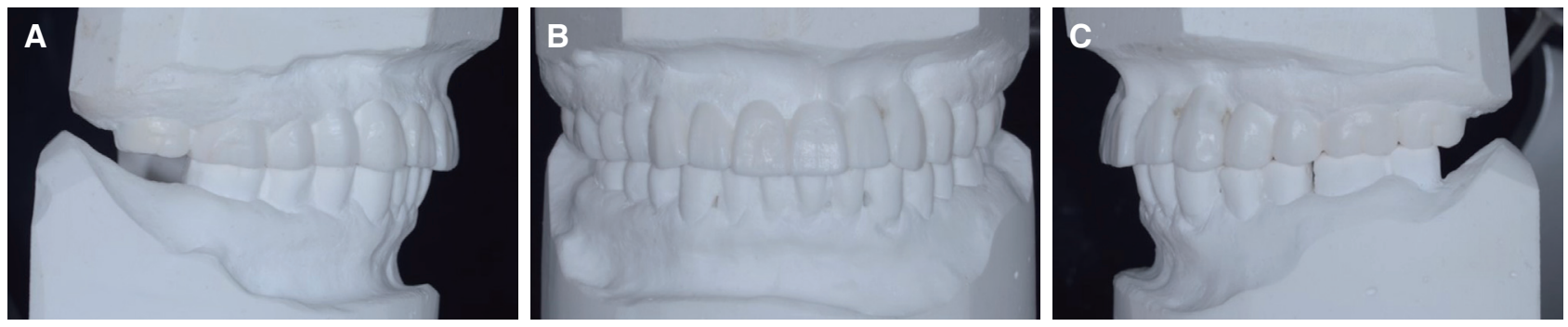

Fig. 6. Diagnostic wax up without any change in the occlusal vertical dimension. There was enough space for the prosthesis. The distance between both bottoms of labial vestibules of upper and lower casts was $35.0 \mathrm{~mm}$ which is the average distance in Korean adults with natural dentition. (A) Right side view, (B) Frontal view, (C) Left side view.

환자는 가철성 보철치료에 대한 강한 거부감을 지니고 있었으며, 고정성 보철치료를 간절히 원하였다. 또한 고 령의 나이와 심장질환으로 인해 임플란트 시술이 어려운 상황이었다. 그리하여 임플란트 식립 없이 상악 전악 고 정성 보철 치료를 진행하였다.

구치부 지지, 발음, 악간 공극 및 안모 평가를 통해 수 직 고경 분석을 시행하였으며, 상대적으로 안정적인 중 심교합위에서의 구치부 지지 및 $3 \mathrm{~mm}$ 의 적절한 자유 공 극(freeway space)을 유지하고 있었고, 발음과 안모 평가 에 있어서도 큰 문제점을 발견하지 못하였다. ${ }^{4}$ Willis 분 석 시 동공간선에서 구각부까지의 거리와 비주인중 경계 부에서 턱 끝까지의 거리의 비가 1:0.97로 나타나 평균치 인 1:1과 유사한 수치를 보였으며(Fig. 4), ${ }^{6}$ 상하악 순측 전정간 거리 또한 $35 \mathrm{~mm}$ 로 한국 성인 유치악자 평균 수
치인 $35 \mathrm{~mm}$ 와 일치하는 수치를 보였다. ${ }^{7}$ 이에 상대적으 로 수직교합고경은 일정하게 유지되었으며, 보철물 수 복을 위한 공간 또한 충분하다고 판단되어 수직교합고 경을 유지한 상악 전악 구강회복술(Maxillary full arch rehabilitation)을 계획하였다.

안궁이전을 시행하여 환자의 상악 모형을 반조절성 교합기(Protar evo5, KaVo Dental GmbH, Biberach, Germany)에 마운팅하였고(Fig. 5), 환자의 중심 교합 위를 채득하여 마운팅된 상악 모형에 맞춰 하악 모형을 마운팅하였다. 수직교합고경을 유지한 채 진단 왁스업 을 시행하였으며(Fig. 6), 자가중합레진(Alike, GC Co., Tokyo, Japan)을 사용하여 \#13, 12, 11, 24, 26, 27을 지 대치로 하는 임시 보철물과 \#17, 15,14 를 지대치로 하 는 임시 보철물을 제작하였다. 2 도 이상의 동요도를 보인 
\#16, 21, 25를 발치하였으며, 치아치조농양의 원인치로 진단된 \#36 또한 extensive pontic 부위와 함께 발치를 시행하였다. 상악 잔존 치아 삭제 후 미리 제작된 임시 보 철물을 구강 내 조정 및 장착하였다. \#17의 원심면 우식 제거 후에도 지속적인 동통을 호소하여 신경치료를 진행 하였다. 임시 보철물 장착 후 3 개월 간의 치유 및 관찰 기 간을 가졌으며, 해당 기간 동안 환자는 저작, 발음, 심미 등에 있어 불편감을 호소하지 않았으며, 임시 보철물 또 한 문제점 없이 환자의 구강 내에서 기능하였다(Fig. 7).
최종 치아 삭제를 시행한 후, polyvinylsiloxane 인상재 (Delikit, Happiden, Seoul, Korea)를 이용하여 인상 채 득을 시행하였다(Fig. 8). 기존 수직교합고경 유지를 위 해 임시 보철물을 이용하여 anterior jig를 제작하였으며, 제작된 anterior jig 및 구치부 임시 보철물을 이용하여 기존 수직교합고경을 유지한 중심교합위를 채득하였다 (Fig. 9). 상악 full contour wax up을 제작(Fig. 10) 및 확 인 후 상악 양측 구치부 교합면이 형성된 고정성 보철물 의 금속 코핑(VeraBond 2V, AalbaDent, Fairfield, USA)
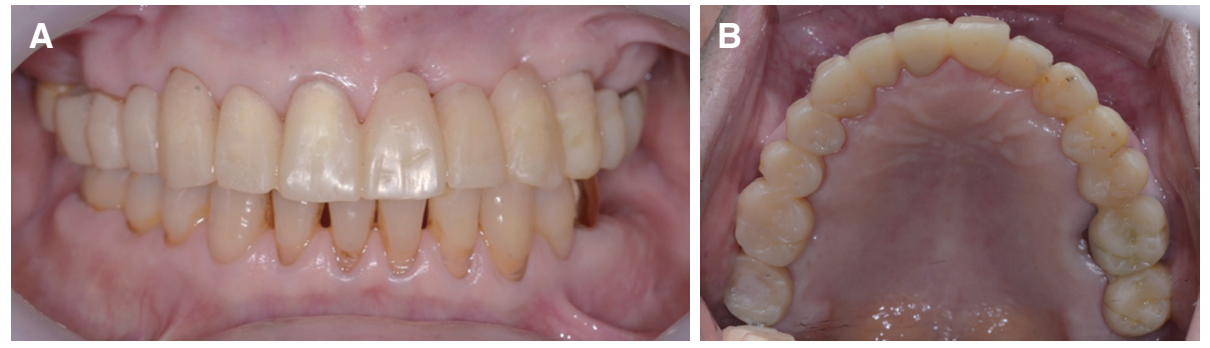

Fig. 7. Provisional restoration after 3 months. Provisional restoration functioned in the patient's mouth without any problems in mastication, pronunciation, and esthetics. (A) Frontal view, (B) Maxillary occlusal view.
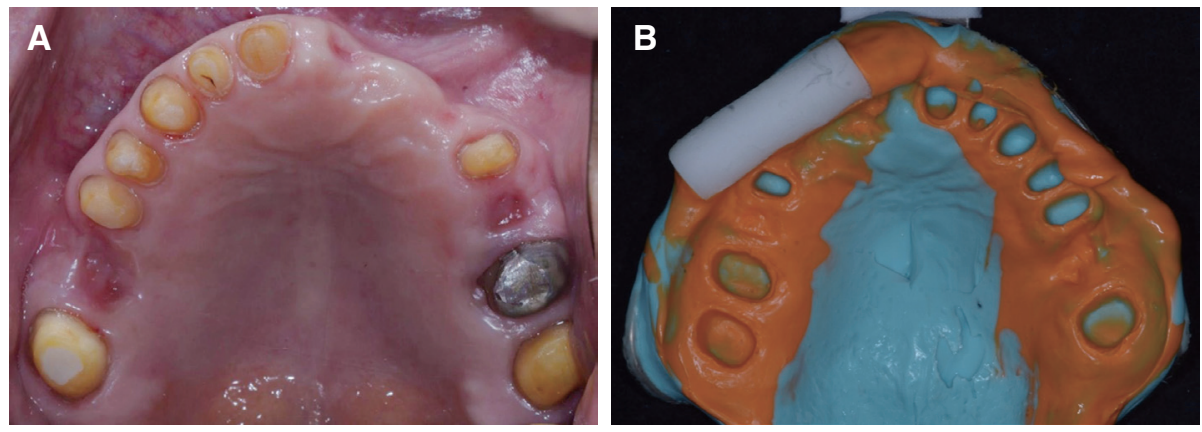

Fig. 8. Final abutment preparation and impression taking for definitive prosthesis. (A) Maxillary abutment preparation, (B) Maxillary abutment impression.
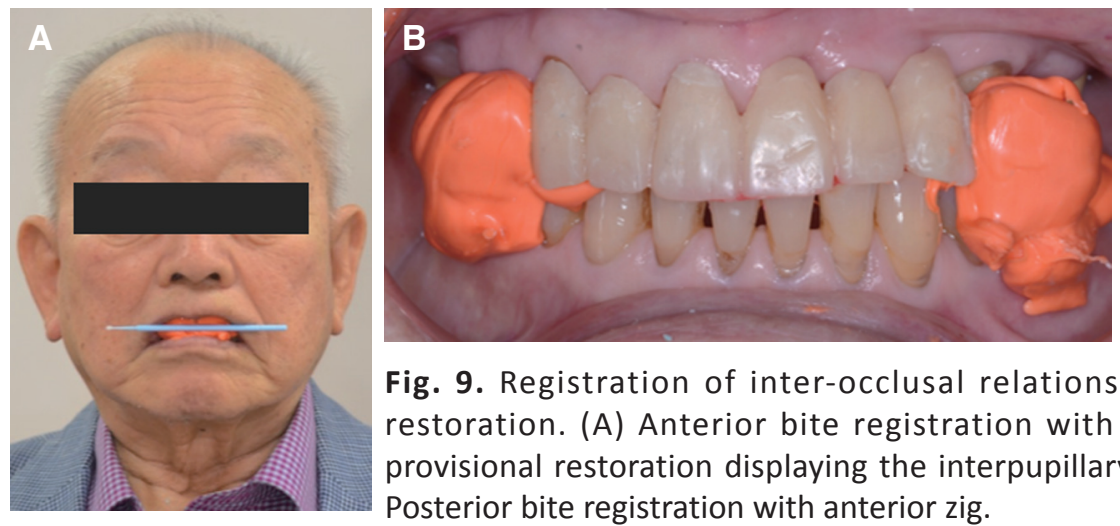

Fig. 9. Registration of inter-occlusal relationship with provisional restoration. (A) Anterior bite registration with posterior portion of provisional restoration displaying the interpupillary line and midline, (B) Posterior bite registration with anterior zig. 
을 제작하여 환자의 구강 내 시적하였으며, 채득된 악간 관계를 재확인하고자 금속 코핑이 시적된 상태에서 중심 교합위를 한번 더 채득하였다. 중심교합위 확인 후 도재 (Super porcelain EX-3, Noritake, Aichi, Japan)를 축성 한 최종 금속 도재 수복물을 제작하였으며, 환자의 구강 내 장착을 시행하였다(Fig. 11).

초진 시 환자의 교합 양식은 양측 구치부에서 군기능 교합 양식을 보이고 있었으나 부적절한 전방유도로 인해
구치부의 지연된 이개를 보이고 있었다. 상악 편악 구강 회복술에 따라 교합 양식의 변화가 가능하였으며, 이에 전방유도 시 즉시 구치 이개를 부여하였고, 측방 운동 시 양측 모두 군기능 교합 양식을 부여하였다. ${ }^{8}$

이후 주기적인 내원을 통해 교합검사 및 구강위생관리 교육을 시행하였으며, 안정적이고 균등한 교합 접촉을 확인할 수 있었다(Fig. 12,13).
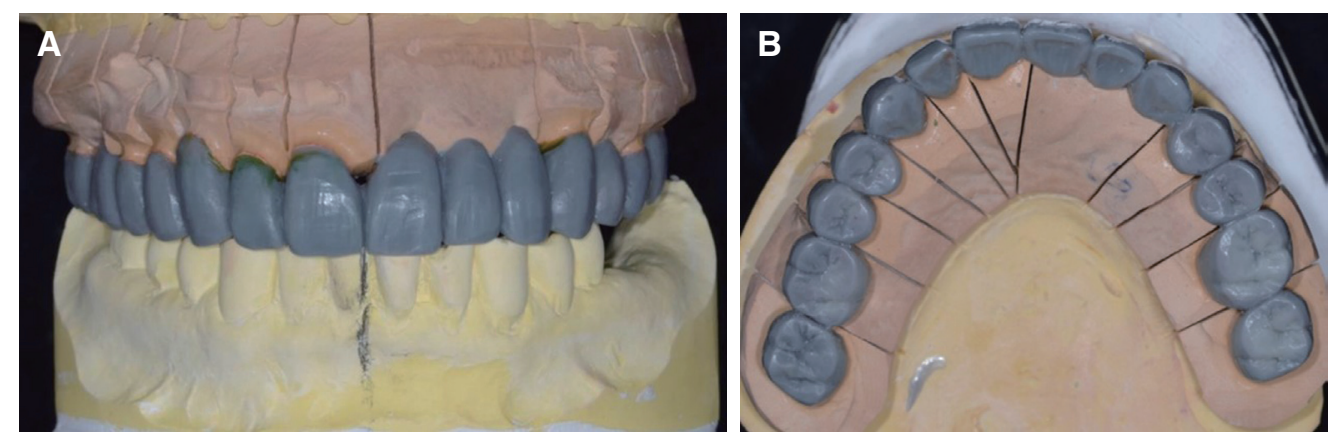

Fig. 10. Full contour wax up for definitive prosthesis. (A) Frontal view, (B) Maxillary occlusal view.
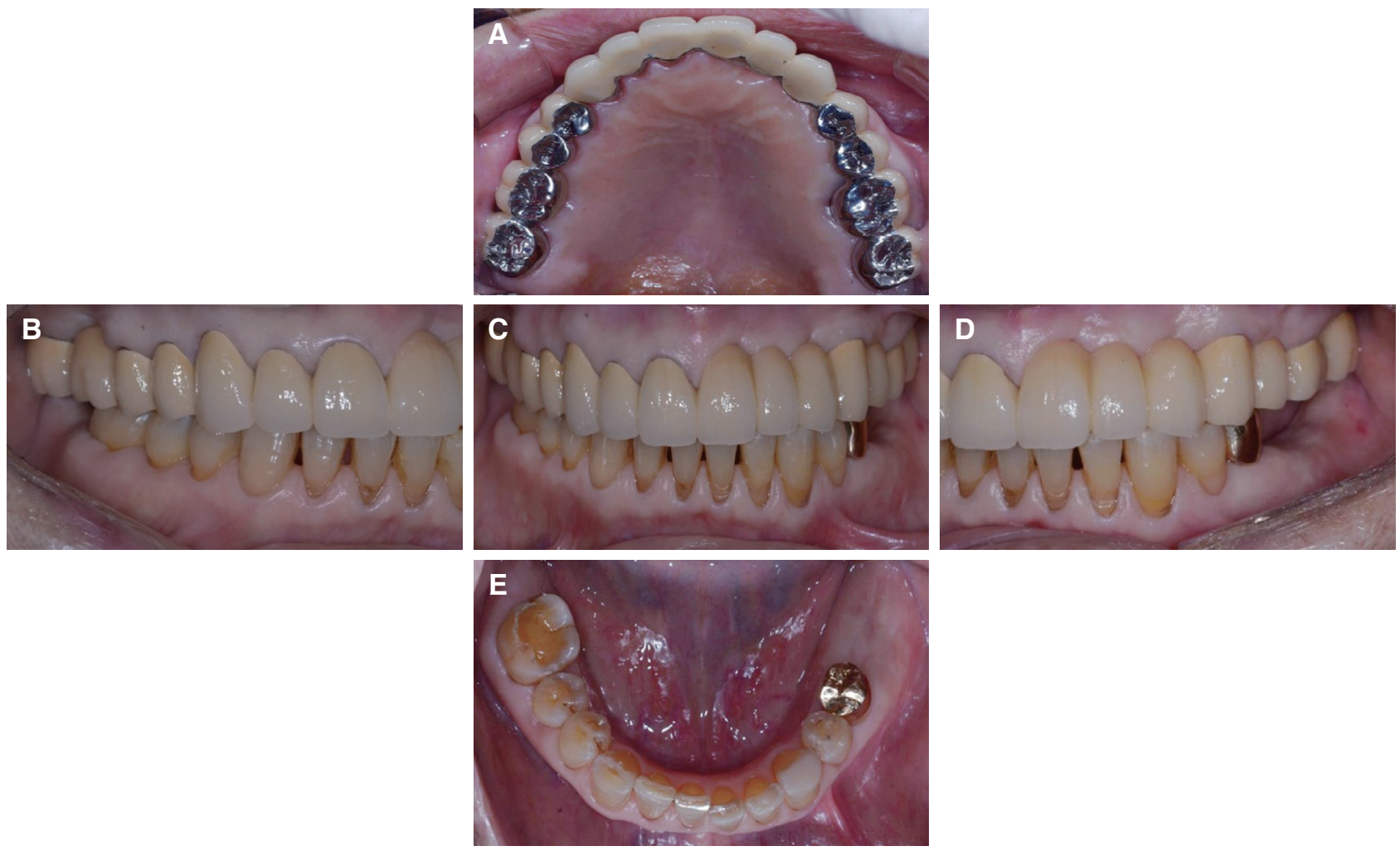

Fig. 11. Definitive prosthesis was delivered. Esthetics and function were restored with the PFM prosthesis. (A) Maxillary occlusal view, (B) Right lateral view, (C) Frontal view at maximum inter-cuspal position, (D) Left lateral view, (E) Mandibular occlusal view. 


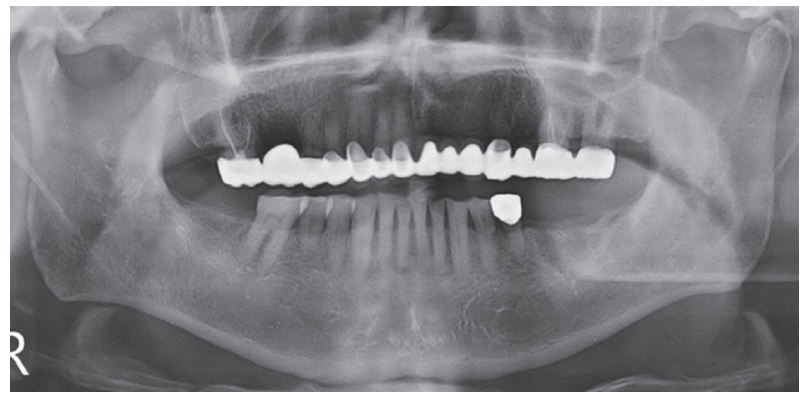

Fig. 12. Panoramic radiographic image after definitive prosthesis delivery. No additional pathologic change was seen.
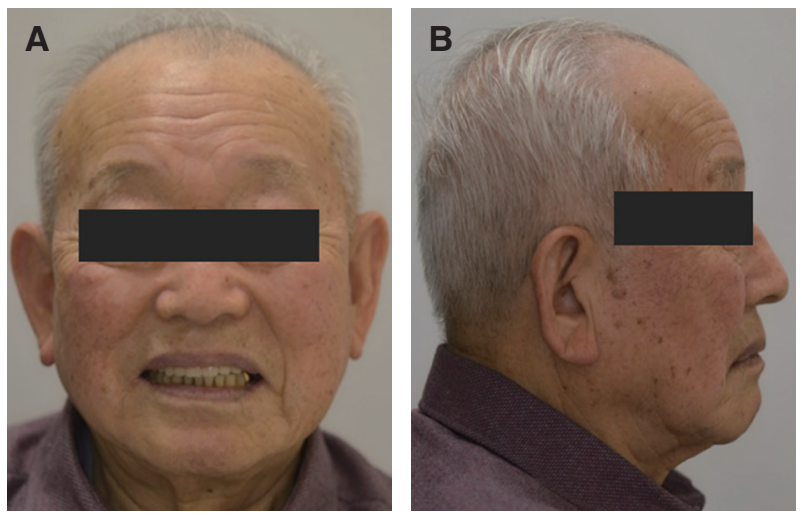

Fig. 13. Extra-oral photos after definitive prosthesis delivery. Stable occlusion was observed. (A) Frontal view, (B) Lateral view.

\section{고찰}

노인 환자의 치아 상실률이 낮아짐에 따라 잔존치에서 발생하는 생리적 마모는 증가하는 추세이다. ${ }^{1}$ 생애주기 에 따라 서서히 진행되는 생리적 마모는 치과 치료의 대 상으로 여겨지지 않는 경우가 많다. 하지만 이러한 생리 적 마모 또한 경우에 따라 치과 치료를 필요로 하게 된 다. 마모에 따라 전방 및 측방 운동 시 정상적인 유도를 얻지 못할 경우 과두 및 저작근에 부정적 영향을 끼치게 되고, 지속적인 마모로 인해 저작기능이 저하된다. ${ }^{9}$ 또한 마모에 따른 지속적인 법랑질 상실은 상아질의 노출을 초래하게 되며, 내마모성이 낮은 상아질의 노출로 인해 치수가 노출되는 상황까지 발생 가능하다. ${ }^{10}$

치과를 찾는 노인 환자 대부분이 틀니와 같은 가철성 보철 치료보다는 기능 및 심미적인 부분에서 장점을 지니 는 고정성 보철 치료를 선호하고 있다. ${ }^{11}$ 가철성 보철 장
치 사용 시 대부분의 환자들은 헐거움과 통증 발생을 호 소하게 되며, 구강위생관리에 있어서도 불편감을 호소한 다. ${ }^{12}$ 예후에 있어서도 고정성 보철 치료의 경우 더 양호 한 치료 결과를 보이며, 가철성 장치 장착 시 더 높은 충 치 유병, 치은 퇴축 및 지대치 동요도 발생이 보고되고 있 다. ${ }^{12,13}$

더욱이 고령의 나이로 인해 임플란트 수술이 어려운 환 자의 경우 가철성 보철 치료를 원하지 않는다면 잔존치 를 이용한 고정성 보철 치료를 계획할 수 밖에 없게 된다. 이 같은 경우 임플란트 식립으로 인한 추가적인 비용 발 생을 줄일 수 있고, 특히나 치주질환에 이환된 환자의 경 우 임플란트 주위염에 취약할 수 밖에 없다는 점을 고려 한다면 기존 자연치를 이용한 고정성 보철 치료는 고령 의 환자에게 있어 선택할 수 있는 좋은 치료 방법들 중 하나이다. ${ }^{14}$

고령 환자에 있어서 잔존치를 이용한 고정성 보철 치료 의 경우 지대치의 위치 및 교합관계 등의 생역학적인 측 면에서 젊은 환자들과는 근본적으로 다른 접근이 필요하 며, 고정성 보철물의 지대치 선정에 있어서도 보다 자유 롭게 선택이 가능하다. ${ }^{5,15}$

본 증례에서는 Ante's law를 감안하여 \#13, 12, 11, 24 를 지대치로 하는 고정성 보철물과 \#25를 extensive pontic 부위로 하며 \#26을 지대치로 하는 캔틸레버 고 정성 보철물을 키와 키웨이 부착형 유지 장치(key and keyway attachment)로 연결하는 비고정성 연결장치를 계 획하였다. ${ }^{16}$ 하지만 \#24, 26의 동요도 고려 시 고정성 연 결장치가 비고정성 연결장치 보다 치주 부착부가 감소된 치아에 더 유리하며, ${ }^{16,17} \# 36,37$ 이 상실된 하악 좌측 구 치부와의 교합상태 고려 시 key가 위치하는 \#25 후방 구 치부에 교합력이 없거나 적을 경우 과맹출 될 가능성을 감안하여, ${ }^{16} \# 13,12,11,24,26,27$ 을 지대치로 고정성 연결장치를 이용한 고정성 보철물을 계획하였다. \#24, 26의 동요도 및 long span fixed dental prosthesis에서 의 유리한 치관 대 치근비(crown-root ratio)를 고려하여 \#27을 지대치로 포함시켰다. ${ }^{18}$

구치부 지지, 발음, 악간 공극 및 안모 평가를 통한 수 직 고경 분석 결과 수직교합고경의 변화가 필요 없다고 판단하였고, 초진 시의 수직교합고경을 유지한 채 \#13, $12,11,24,26,27$ 을 지대치로 하는 임시 보철물과 \#17, 15,14 를 지대치로 하는 임시 보철물을 제작하였다.

임시 보철물 제작 시 구치부의 즉시 이개가 가능한 전 방유도를 부여하였으며, 측방 운동 시 기존 교합 양식을 
고려하여 양측 모두 군기능 교합을 부여하였고, ${ }^{8}$ 비작업 측 구치부 이개를 유도하였다. 이후 임시 보철물 상태에 서 환자의 적응여부를 3 개월에 걸쳐 관찰하였으며, 해당 기간 동안 임시 보철물의 파절이나 지대치의 동요도 증 가 등은 관찰되지 않았다.

최종 보철물은 long span fixed dental prosthesis의 margin 적합도를 고려하여 금속 도재관을 이용하여 제 작하였으며, ${ }^{19}$ 이후 주기적인 경과관찰을 시행하였다. 키와 키웨이 부착형 유지 장치와 같은 완압 장치(stress breaker)를 사용하지 않음으로써 환자 스스로 구강 위생 관리 및 유지가 더 용이해졌으며, ${ }^{20}$ 안정적인 교합상태를 보였고, 심미 및 기능적으로 만족할만한 결과를 얻을 수 있었다.

\section{결론}

본 증례에서는 기존 보철물의 동요도 및 생리적 마모 를 보이는 고령 환자에 대해 Willis 분석 및 악간 공극, 발 음, 진단 납형의 제작을 통하여 수직교합고경을 평가하 였고, 기존의 수직교합고경을 유지한 long span의 임시 보철물을 제작하여 3 개월에 걸쳐 환자의 기능적, 심미적 적응 여부를 확인하였다. 이후 최종 보철물을 제작 및 장 착하였고, 경과 관찰한 결과 특이할 만한 합병증은 관찰 되지 않았으며, 일련의 치료 과정을 통해 만족할만한 결 과를 얻을 수 있었다. 추후 장기적인 보철물의 예후를 위 해 정기적인 경과관찰이 필요할 것으로 사료된다.

\section{ORCID}

Jae-Hyun Lee http://orcid.org/0000-0001-7426-5667 Jae-Jun Ryu http://orcid.org/0000-0001-6903-5955

\section{References}

1. Donachie MA, Walls AW. Assessment of tooth wear in an ageing population. J Dent 1995;23:15764.

2. Dawson PE. Functional occlusion: from TMJ to smile design. St. Louis; Mosby; 2007. p. 430-52.

3. Ramfjord SP, Blankenship JR. Increased occlusal vertical dimension in adult monkeys. J Prosthet Dent 1981;45:74-83.

4. Turner KA, Missirlian DM. Restoration of the extremely worn dentition. J Prosthet Dent 1984;52:467-74.

5. Lloyd PM. Fixed prosthodontics and esthetic considerations for the elder adult. J Prosthet Dent 1994;72:525-31.

6. Willis FM. Features of the face involved in full denture prosthesis. Dent Cosmos 1935;77:851-4.

7. Park JH, Jeong CM, Jeon YC, Lim JS. A study on the occlusal plane and the vertical dimension in Korean adults with natural dentition. J Korean Acad Prosthodont 2005;43:41-51.

8. McAdam DB. Tooth loading and cuspal guidance in canine and group-function occlusions. J Prosthet Dent 1976;35:283-90.

9. Luke DA, Lucas PW. The significance of cusps. J Oral Rehabil 1983;10:197-206.

10. Ingle JI. Alveolar osteoporosis and pulpal death associated with compulsive bruxism. Oral Surg Oral Med Oral Pathol 1960;13:1371-81.

11. Jepson N, Allen F, Moynihan P, Kelly P, Thomason M. Patient satisfaction following restoration of shortened mandibular dental arches in a randomized controlled trial. Int J Prosthodont 2003;16:40914.

12. Mojon P, Rentsch A, Budtz-Jørgensen E. Relationship between prosthodontics status, caries, and periodontal disease in a geriatric population. Int J Prosthodont 1995;8:564-71.

13. Budtz-Jørgensen E, Isidor F. A 5-year longitudinal study of cantilevered fixed partial dentures compared with removable partial dentures in a geriatric population. J Prosthet Dent 1990;64:42-7.

14. Heschl A, Haas M, Haas J, Payer M, Wegscheider W, Polansky R. Maxillary rehabilitation of periodontally compromised patients with extensive onepiece fixed prostheses supported by natural teeth: a retrospective longitudinal study. Clin Oral Investig 2013;17:45-53.

15. Gordon SR, Lloyd PM. Fixed prosthodontics in the elderly population. Life expectancy of fixed restorations, failures, and retreatment methods. Dent Clin North Am 1992;36:783-95.

16. Shillingburg HT, Sather DA, Wilson EL, Cain JR, Mitchell DL, Blanco LJ, Kessler JC. Fundamentals of fixed prosthodontics. 4th ed. Chicago; Quintes- 
sence Publishing Co.; 2012. p. 81-98.

17. Landry KE, Johnson PF, Parks VJ, Pelleu GB Jr. A photoelastic study to determine the location of the nonrigid connector in a five-unit intermediate abutment prosthesis. J Prosethet Dent 1987;57:454-7.

18. Reynolds JM. Abutment selection for fixed prosthodontics. J Prosthet Dent 1968;19:483-8.

19. Hung SH, Hung KS, Eick JD, Chappell RP. Mar- ginal fit of porcelain-fused-to-metal and two types of ceramic crown. J Prosthet Dent 1990;63:26-31.

20. Heschl A, Haas M, Haas J, Payer M, Wegscheider W, Polansky R. Maxillary rehabilitation of periodontally compromised patients with extensive onepiece fixed prosthesis supported by natural teeth: a retrospective longitudinal study. Clin Oral Investig 2013;17:45-53. 


\section{마모된 치열을 지닌 고령 환자의 상악 전악 고정성 수복 증례}

\section{이재현, 최연조, 류재준*}

고려대학교 안암병원 치과 보철학교실

노인 환자 구강의 생리적 변화 중 하나인 생리적 치아 마모는 일반적으로 치료를 필요로 하지 않으나 교합 부조화, 저작 기능의 저하, 치수 노출 등 구강 내 문제 발생 시 보철 수복을 필요로 한다. 마모된 치열을 지닌 환자의 보철 수복 시 우선 적으로 고려되는 사항들 중 하나가 바로 수직고경에 대한 고려이다. 이에 정확한 진단 및 분석과 예지성 있는 치료계획을 위한 악간관계에 대한 올바른 판단이 요구되며, 노인 환자의 치과 치료를 감안한 단계별 치료접근을 필요로 한다. 본 증 례는 93세 남자 환자로 전반적인 치아 마모 및 기존 고정성 보철물의 동요도를 보이고 있었다. 진단 및 평가 후 수직교합 고경을 유지한 상악 구강회복술을 시행하였으며, 기능 및 형태적으로 만족할만한 결과를 보여 보고하는 바이다.

(구강회복응용과학지 2017;33(2):154-62)

주요어: 노인 환자의 치과 치료; 치아 마모; 수직고경 